Article

\title{
Earning God through the "One-Hundred Rupee Note": Nirguna Bhakti and Religious Experience among Hindu Renouncers in North India
}

\author{
Antoinette DeNapoli \\ Department of Religion, Texas Christian University, 2800 S University Dr, Fort Worth, TX 76129, USA; \\ a.denapoli@tcu.edu
}

Received: 9 November 2018; Accepted: 6 December 2018; Published: 11 December 2018

\begin{abstract}
This article examines the everyday religious phenomenon of nirguna bhakti as it is experienced by Hindu renouncers (sādhus) in North India. As an Indian language concept, nirguna bhakti characterizes a type of devotion (bhakti) that is expressed in relation to a divinity who is said to be without (nir) the worldly characteristics and attributes of sex and gender, name and form, race and ethnicity, class and caste. Although bhakti requires a relationship between the devotee and the deity, the nirguna kind transcends the boundaries of relational experience, dissolving concepts of "self" and "other", and, in effect, accentuating the experience of union in the divine absolute. In comparison to saguna bhakti (devotion to a deity with attributes), nirguna bhakti is considered to be difficult to realize in human birth. Yet, the poetry, songs, and practices of uncommon humans who have not only left behind social norms, but also, devoting their lives to the worship of the divine, achieved forms of divine realization, people like the mystics, saints and sādhus of Hindu traditions, laud the liberating power and insights of nirguna bhakti. The Hindu sādhus featured in this article describe their experiences of nirguna bhakti through the use of the idiom of a "one-hundred rupee note" to distinguish its superior value and, as significantly, to indicate that humans "earn" God (Brahman) through the practice of nirguna devotion. As a "precious" spiritual asset on the path of liberation, nirguna bhakti establishes the religious authority and authenticity of sādhus, while setting them apart from other sādhus and holy figures in a vibrant North Indian religious landscape.
\end{abstract}

Keywords: Hinduism; renunciation; Nirguna Bhakti; devotion; performance; Sadhus; India

Wherever you look, God is there. But we can't see God. We can't do anything without God. We can't move our limbs, or blink our eyes, or even breathe without God. Only God does everything. Only God moves everything. Only God causes us to speak and to see. God feeds us and quenches our thirst. God wakes us up in the morning and puts us to sleep at night. God raises us. Only God does everything. These bodies of ours are like stones. And when these bodies die, God emerges. God is the most precious thing we have in this world. Whether you bury it or burn it, the body has no worth. It is not even worth a single rupee. If you want to meet God, then you have to offer God the devotion that is worth a single one-hundred rupee note. And God will meet us, for sure.

Ganga Giri Maharaj, March 29, 2005, India

This article explores the religious phenomenon known as nirguna bhakti in the Hindu traditions through the religious experiences and devotional practices of the Hindu mystics and holy people 
(sādhus) with whom I have worked in North India for almost two decades. ${ }^{1}$ The research for this article is based on ethnographic fieldwork that I conducted with a population sample of thirty-nine Hindu sādhus (24 women and 15 men) in five districts of the former princely state of Mewar in southern Rajasthan. ${ }^{2}$ While the sādhus speak Hindi (or a local Rajasthani dialect mixed with modern Hindi), to make this article's transliteration practices systematic with the rest of the articles also featured in this special issue, and user-friendly for non-Indian language speakers, I follow the more common academic convention of using the Sanskrit spelling of Indian language terms, such as nirguna (rather than the Hindi version, nirgun), mokșa (H: mokș), sannyāsa (H: sannyās), guna (H: gun), and so forth. ${ }^{3}$ The exception to this standard concerns the names of Hindu deities, which correspond to the sādhus' Hindi pronunciation. Here, the sādhus say "Ram", and not Rama; "Shiv", and not Shiva, etc.

Bhakti translates to mean "loving devotion", and the concept of nirguna calls attention to a unique kind of bhakti that centers on the worship of a God who is said to have no defining characteristics, qualities, or traits (guna). Although bhakti implies relationship between the devotee and the deity, the nirguna kind transcends the parameters of relational experience, dissolving concepts of "self" and "other", and, in effect, accentuating an experience of union with the impersonal divine. As illustrated in the epigraph to this article, Ganga Giri, a woman sādhu with whom I worked, and whom the other sādhus considered an exemplary sādhu by virtue of her realizing (non-dual) Brahman consciousness, describes a nirguna understanding of the divine. ${ }^{4}$ As Brahman has no shape or form, it cannot be seen. Yet, the impersonal divine can, indeed, be known. It not only "drives" everything in the universe, but it also exists within all forms of creation, waiting to be experienced. We will return to this idea shortly.

Historically, nirguna bhakti dates back approximately to the 15th century in North India in connection with the devotion exemplified by spiritually realized people known as the "sants" (literally, the "good people"), who gathered in fellowship (satsang) to sing to a nameless and formless God. Its practice runs across Indic religious traditions and it is featured in the bhakti poetry of Hindus, Sikhs, and (Sufi) Muslims. Take examples like Guru Nanak (ca. 1469), who founded the Sikh tradition. In teachings (guru-vānñ) that have been enshrined in the Guru Granth Sāhib, the Sikh scripture, Guru Nanak says that chanting the "indestructible" name (śabda) of the "timeless", "colorless", and "formless" God brings peace to the heart. Subsequently, there is Kabir (ca. 1440), the "exemplar of nirguna religion". ${ }^{5}$ As a sant claimed by Hindus and Muslims, and casting his vitriol at oppressive social structures and institutions, Kabir sings of the brilliance of the formless God (Ram), while cautioning against becoming absorbed in meaningless labels like "Hindu" or "Muslim". In a poem attributed to him, Kabir says:

If God had wanted to make me a Muslim,

why didn't he make the incision?

You cut away the foreskin, and then you have a Muslim;

so what about your women?

What are they?

Women, so they say, are only half-formed men:

I guess they must stay Hindus to the end.

Hindus, Muslims—where did they come from?

Who got them started down this road?

1 The research was funded by a Junior Scholars Dissertation Research Fellowship with the American Institute of Indian Studies (AIIS). The AIIS also awarded me an advanced Hindi language fellowship for the academic year 2002-2003, which made it possible for me to return a year later to Rajasthan and conduct ethnographic field research with the sādhus.

2 (DeNapoli 2014).

3 As readers can see, In the Hindi pronunciation of Sanskrit terms, the final 'a' of a word remains unpronounced.

4 To accentuate narrative voice, in this article, I use the ethnographic present to describe the practices and lives of the sādhus with whom I worked. By doing so, I hope to evoke for readers the ethnographic presence of their teachings and the ways that their words/songs emerged in my interactions with them.

5 (Hawley and Juergensmeyer [1998] 2008), p. 41. 
Search inside, search your heart and look:

Who made heaven come to be?

Fool,

Throw away that book, and sing of Ram.

What you're doing has nothing to do with him.

Kabir has caught hold of Ram for his refrain,

And the Qazi ${ }^{6}$ ?

He spends his life in vain. ${ }^{7}$

Nirguna bhakti characterizes one of two types of devotion in the Hindu traditions. The other type is known as saguna, which describes loving devotion to a deity who is imagined to have any and every kind of attribute conceivable with respect to name, form, and gender. Saguna forms of deity range from the anthropomorphic (imagining God as human) to the theriomorphic (imagining God as an animal). In saguna traditions, like Vaishnvaism, the great Hindu god Vishnu, around whom Vaishnava worship revolves, is said to have ten descent-forms (avatāra) by which the god incarnates in the world to save it from destruction and evil (adharma). Among Vishnu's avatāras are humans (e.g., Ram, Parashuram, Krishna), a dwarf, a half-man/half-lion, a boar, a tortoise, a fish, and one final form, Kalki, which has yet to appear, but, according to Hindu texts and popular religious understandings, will come during the end times. ${ }^{8}$

Unlike saguna worship, however, nirguna experience transcends the familiar epistemological boundaries of human thought, including those of space and time, to propel the devotee into sacred experience that is unimaginable to the human mind. Therein lies its appeal and its goal: the total transcendence of all (human-created and socially sanctioned) distinctions of self and other, right and wrong, the beautiful and the grotesque, pure and impure, young and old, rich and young, male and female. The list goes on and on. Not surprisingly, as the Kabir poem attests, nirguna bhakti voices through the poetry of the sants and, in our times, through the practices of the sādhus who sing the songs of the sants, socially uplifting messages about transcending social differences, because, "in light of the experience of sharing in God, all social distinctions lose their importance". 9 Furthermore, as the voluminous nirguna bhakti literature suggests, transcendence experienced as the dissolution of differences forges the union of the devotee's self ( $\bar{a} t m \bar{a})$ with God-Self (Brahman), which the sādhus call "melting into God", to bring about an ultimate state of peace (śānti), equanimity, and stillness. To clarify: many of the following bhajans sung by the sādhus refer to the divine as "Ram", which characterizes nirguna understandings of the nameless, formless, and genderless absolute, and not saguna interpretations of Vishnu's avatāra, Ram.

We will examine the ways in which the Hindu sādhus talk about, and, more precisely, sing about nirguna bhakti, and why they prefer this bhakti over the saguna kind. We approach our analysis of nirguna bhakti through the lens of the lives and teachings of the sādhus because these individuals spend their days striving to realize the impersonal absolute through the nirguna bhakti path in order to attain the ultimate goal of liberation (mokṣa) from the endless cycle of birth, life, and death, known as samsāra. While there are many kinds of sādhus in South Asia, this articles draws the reader's attention to a specific class of sādhus known as renouncers. The Indian language term for a male renouncer is sannyāsī, and sannyāsinī is used for the female renouncer (the latter are also called "māī", "māī-rām", or "mātā-rām", all of which translate to mean "holy mother"). Despite the terminological specificity by which renouncers as a class are characterized in South Asia, those with whom I worked preferred

\footnotetext{
"Qazi" translates to mean a Muslim religious professional who specializes in legal interpretations of the Quran Ibid., p. 52.

See (Dimmitt and van Buitenen 1978)

Ibid., p. 17.
} 
the generic term "sādhu" to represent themselves (some called themselves sants, or "good people") and this preference cuts across gender, class, and caste.

There are two major types of Hindu renunciation in India, namely Shaiva and Vaishnava forms. The Shaiva traditions traditionally accept the great Hindu god Shiv as the divine absolute, whereas the Vaishnava traditions acknowledge Vishnu in this role. The sādhus with whom I worked belong to one of two Shaiva traditions of renunciation: The Dashanami (literally, "ten names") tradition of sādhus, which is thought to have been organized by the Hindu renouncer (and reformer) Adi Shankara (ca. 9th century), who established monasteries throughout India; the Gorakhnath Kanphata Yogi tradition (henceforth, Nath), attributed to the Hindu mystic-saint, Gorakhnath (ca. 11th century).

As renouncers, the sādhus practice an unconventional way of life in India, called sannyāsa ("world renunciation"). It demonstrates a radical religious option in South Asia as well as illuminates an alternative to the dominant social norm of householding. The sādhus have left behind the normative societal expectations of marriage and family, socio-economic obligations of work and career, class and caste (and the social status and privilege that are associated with different caste communities), and their broader social responsibilities to the community (samāj) or society in which they lived, participated, and mapped their everyday lives. As they are required to relinquish making money, the sādhus are not wage earners. They rely on the kindness and generosity of their householder devotees to sustain themselves physically in the world, and the sādhus return that generosity by giving teachings, counsel, healing, guidance, and blessings.

After taking their vows, which involve voluntary simplicity, poverty, and life-long celibacy (brahmacārya), and after undergoing the ritual ceremony (sanskāra) and initiation (dīkșā) by which they sever their socio-biological ties to their former social worlds, the sādhus embark on a religious path that is dedicated to the salvific goal of "getting God", so as to stop any further journeying in samsāra. As the term denotes "endless wandering" from lifetime to lifetime due to infinite numbers of rebirths, the sādhus view samsāra in a negative way. They perceive samsāra as a transitory realm of "death", "pain", and "suffering", and they hope to exit from it not only as quickly as possible, but also with the liberating insight (jnāna) that ensures they will never return to the world.

A way of life that requires its practitioners to "die and then live" is by no means for the faint of heart. Sādhus are commonly revered and respected on account of the physical, mental, and spiritual hardships that are associated with sannyāsa (but sādhus can also evoke suspicion and doubt because, as they relinquish their ties to the world, no one knows who they are, where they come from, or what their intentions are). As the sādhus told me, sannyāsa is "difficult" and it requires a lifetime of patience, persistence, and perseverance. Some of the sādhus recognize that they may "return" to samsāra the next time around; however, through the good works (karma) that they have accumulated from the current life of discipline (sādhan $\bar{a})$, these sādhus also feel that they will be reborn as sādhus and realize mokșa in a future birth. Others, though, are less thrilled by that possibility and remain determined to realize mokșa in this lifetime.

The central renunciant virtues around which the sādhus weave their worlds concern those of detachment (vairāgya), solitude (ekānta), and simplicity (saraltā). Of these, detachment figures prominently. In the dominant view of the "rhetoric of renunciation", as "performed" by the sādhus through the means of song, story, and sacred text, detachment distinguishes the "real" (asli) from the "fake" (naklī) sādhus; the dilettantes from the earnest. Detachment makes possible sādhus' expected cutting of ties with family, community, society, and world, and leads them, as one Hindu mystical text describes, from "death to immortality".10 Thus, viewing their lives as a sacred offering of prayer and loving devotion to God, the sādhus engage in practices through which they generate detachment from worldly concerns, needs, and desires. For many of the sādhus, nirguna bhakti provides

10 Brihadāranyaka Upaniṣad, 1.3.28, cited from (Olivelle 1996), pp. 12-13. 
a powerful conduit with which to engender detachment and realize the impersonal divine absolute in the current birth.

In comparison to the saguna variety, nirguna bhakti commands the adoration of the sādhus (and the householders) whom I knew. It can do what these sādhus say no other practice can do: dissolve all social distinctions into emptiness, distinctions like caste (jāt $\bar{\imath})$, class (varna), and sex (linga), which have been used by the dominant Brahmanical religious power structure in the history of Hindu traditions to oppress and disclaim the full humanity of women and low-castes. Along with dissolving worldly dualities, nirguna bhakti is said to reduce the human ego to ashes. Its perceived power to bring sādhus to an ultimate (and fiercely coveted) state of human transcendence in which the divine is revealed to and experienced by the devotee creates the "symbolic capital" of nirguna bhakti for the sādhus. ${ }^{11}$ That is, the sādhus who engage in forms of nirguna devotion are thought to be more accomplished and spiritually evolved by other sādhus and householders than the sādhus who do not. The nirguna worshipping sädhus have high spiritual prestige, as they are seen to be immersed in the God-consciousness that their nirguna bhakti is said to create. Through their performance of the rhetoric of renunciation, the sādhus heighten the significance of nirguna bhakti to sannyāsa by calling it a "one-hundred rupee note", distinguishing it from saguna bhakti, which is often termed a "single one rupee note". Ganga Giri, whose teachings are described earlier in the article, emphasizes the "priceless" value of nirguna bhakti. She sings the following bhajan to foreground her understanding of the primacy of nirguna worship:

O sants, my tongue is singing bhajans.

The bright diamond shining in the body is my satisfaction.

If it shines in you, the diamond will make both your body and mind bright.

We've met the sadguru (true guru) in the form of Ram (nameless/formless God).

We've got the sadguru in the form of bhajans.

We join hands to those walking on the path of bhakti.

My tongue is singing bhajans.

In the seven seas, the water is very deep

In the seven seas, the water is very deep

The real [s $\bar{u} g r \bar{a}]$ devotees are filling their glasses and drinking a lot;

The fake $[n \bar{u} g r \bar{a}]$ devotees are standing on the shore, thirsty.

My tongue is earning bhajans.

O sants, this is what Gorakh and Kabir have said.

The real devotees are walking on the path of bhakti.

In the fort of Chittor, Mira Bai is worshipping Kali

In the fort of Chittor, Mira Bai is worshipping Kali

She had a water pot on her head and released it in the river.

O sants, my tongue is earning bhakti.

O sants, Gorakh and Kabir have said that

The real devotees are walking on the path of bhakti.

O sants, my tongue is earning bhajans.

11 I draw on the work of French sociologist Pierre Bourdieu to describe the idea of the spiritual merit in the form of nirguna knowledge as produced and accumulated by sädhus who practice nirguna devotion as "symbolic capital". Their nirguña knowledge represents a spiritual resource by which the sādhus create and establish their perceived high status and prestige in their communities. See (Bourdieu 1985). 
Don't escape from your body;

It will be filled with diamonds some day

It will be filled with diamonds some day

O sants, my tongue is earning bhajans. ${ }^{12}$

After singing the bhajan, Ganga Giri shares this commentary on nirguna bhakti:

There is no power in this body. The power of this body, the power within all bodies, is God. But God has no shape [ākāra]. God has no form. We call this knowledge Brahma-jnāna [nirguna knowledge of God]. In India, we have a single one-hundred rupee note. You don't have to count it. If it's small change, then you have to count it one by one. Knowledge should be like this-only a single note of one-hundred rupees. This knowledge is precious. It's not so easy to come by. Nirguna bhakti is like that. It's not so easy to live. It's not lying on the side of the road. It is very precious. The name of God [Ram] is very precious. It's the most expensive thing and yet it doesn't cost anything. ${ }^{13}$

As Ganga Giri indicates in her teaching, nirguna bhakti, as realized through devotional singing (bhajans) fills the devotee with the liberating knowledge that enables religious experience of the divine impersonal absolute. To that extent, singing bhajans that illuminate the "precious" nirguna knowledge of the Brahma-jnāna (literally, "ultimate knowledge of the impersonal God") symbolizes the valued religious "currency", in which the sādhus of Rajasthan, and elsewhere in India as the work of other scholars has shown, deal in their daily efforts to "get" God and attain mystical transcendence.

So that the reader may get a rhetorical "taste", or sense, of the religious texture of nirguna bhakti and develop an understanding of how, and the extent to which, the bhajans describe an "impersonal" experience of the divine and why it matters to the sādhus, in the rest of our discussion, we will examine their nirguna bhajans, the themes and motifs accentuated in their songs, and the implications of nirguna worship on the social lives and experiences of the sādhus. The question that frames the following analysis is this: Is an experience of an impersonal absolute possible given first, the ineffability that is implied by that experience (how do we describe that which reaches beyond human conceivability), and second, the dissolving of ego-consciousness (the awareness that " $\mathrm{I}$ " exist morphs into something that defies subjectivity). It seems initially a logical contradiction to experience something that has no attributes or qualities to experience. Let us now see what the sādhus and their songs have to say about this perplexing idea.

\section{Singing the Best Bhakti to God: Nirguna Bhajan Songs and Themes}

\subsection{Theme \#1: Slipping into God: Cultivating an Attitude of Surrender for Nirguna Devotion}

Mystics across religious traditions have often emphasized the ineffability of their personal experiences of union with the divine. Words, symbols, images, metaphors, and emotions fail to accurately and concretely communicate what the divine is and, more precisely, what it feels like to merge with divine consciousness. The sādhus, too, make similar proclamations about experiencing the nirguna Brahman. Be that as it may, as with the writings of mystics throughout time and space, the sädhus never fail to articulate their nirguna experiences in a variety of ways. If pressed to define God, they simply say, "God is love". Most of the time, though, they speak about the nirguna God through the use of religious symbols and metaphors. For example, Ganga Giri says that "meeting" Brahman is "slippery" - meaning that it is neither easily attainable nor easily sustainable in ordinary waking consciousness. The devotee has to work "very hard" to "get" God and maintain God-consciousness.

12 March 29, 2005.

13 March 29, 2005. 
At the same time, the effort the devotee pours into her practice is not a guarantee that she will meet God. It slips from her grasp as soon as she "finds" God. Likewise, the devotee cannot "hold" God, for that would imply that God fits in her hands and can be known by her limited physical senses of touch, sight, sound, taste, and smell. Meeting the nirguna Brahman seems to be a lot like a game of hide and seek. "God", as Ganga Giri says, "is everywhere and nowhere".

Yet, she claims to have experienced through bhajan singing the nirguna reality of Brahman. She says that she has felt God (Brahman; Sain; Parabrahman), but not with her physical senses. Rather, like many of the other sādhus, Ganga Giri says she has experienced God with her "heart-mind" (man). She stresses that the way to "find" Brahman is through the heart-mind, which, as I understand, is akin to the sensory apparatus of the soul $(\bar{a} t m \bar{a})$. "Brahman", Ganga Giri explains, "sits in the heart-mind". Even if it transcends sensory experience, there has to be a means, albeit preliminary, by which the devotee can know Brahman. The heart-mind serves that function. It represents the gateway (dwāra) to the self $(\bar{a} t m \bar{a})$ and to Brahman, and like any door, the heart-mind, too, requires a key to be opened. That key, according to Ganga Giri, lies with cultivating an attitude of surrender to and dependence (adintā $)$ on the divine.

Thus, on the one hand, meeting God demands constant and painstaking effort on the part of the devotee. One never knows, as Ganga Giri suggests, when she will find God, or when God will find her. On the other hand, because experiencing God is "slippery", that effort may be as simple as "letting go" and "surrendering" to God. In this way, Ganga Giri indicates that meeting the nirguna Brahman requires "slipping" into the "ocean" (bhavsāgara) of God-consciousness, of letting go of everything a person often struggles to hold on to, and to which one is attached (e.g., status, name, fame, fortune, ideas) by surrendering to a divine power and presence that is "everywhere and nowhere". Ganga Giri sings this bhajan to explain how to "get God":

Live as God keeps you

Mira Bai would say to the King [Mira's brother-in-law],

Mira Bai said [to the King, her brother-in-law]

Live as Ram keeps you.

'O, King, Live as Ram keeps you'.

Some days there is halvā (sweets) and $p \bar{u} r \bar{\imath}$ (fried bread) to eat.

[And] some days you have to go hungry.

'O, King, live as Ram keeps you'.

Some days you have a pillow and mattress

[And] some days you have to sleep on the floor.

'O, King, live as Ram keeps you'.

Some days you have gardens to wander in.

[And] some days you have to live in the jungle.

'O, King, live as Ram keeps you'. ${ }^{14}$

This bhajan contains the signature (cāp) that is attributed to the woman sant known as Mira Bai. She was born into a royal Hindu (Rajput) household as a princess in the late 15th century in eastern Rajasthan. Mira Bai is said to have left behind not only the comforts and privileges of her royal status, but also her husband, the prince of the Sisodiya clan who hailed from western Rajasthan, and to whom, according to Rajasthani oral traditions, Mira was forced in marriage in order to devote herself to worshiping God through song. For Ganga Giri and many of the sādhus, Mira Bai models the intensity and commitment of loving devotion with respect to surrendering oneself to the divine. To make 
oneself utterly dependent on the nirguna Lord enacts a superior method for worshiping the impersonal divine absolute. When Mira Bai set out from the castle (she left after her in-laws tried to take her life on multiple occasions, as she refused to make her devotion to God secondary to her role as the wife and princess of the Sisodiya ruler), she neither had food, nor water; neither a bed to sleep in, nor a place to live. She was alone and on her own. As the bhajan indicates, Mira understood the nameless and formless "Ram" to be her "real" security and basis for existence. Mira Bai is often associated with saguna bhakti in connection with her worship of Krishna. Yet, the sādhus' performance repertoires demonstrate that nirguna versions of Mira bhakti (in this bhajan, Mira worships the formless "Ram" and not the form of Krishna) circulate among renouncer communities in North India, and thus, illuminate the fluidity of the boundaries of these categories of devotional experience in lived Hindu traditions.

"Without God", as Ganga Giri teaches, "we are nothing". While we tend to think that we steer the course of our lives and destinies, in the sādhus' views, God remains the inner and outer-controller of everything in this world. The bhajan makes this idea explicit through Mira's repeated pleas to the king (her former husband's brother) to "live as God keeps him". That is, Mira implores her brother-in-law to relinquish his attachments to his wealth, his royal status, his kingdom, and perhaps his expectations of Mira as the daughter-in-law of the Sisodiyas, and surrender to the impersonal Ram, as nothing in this world compares to the "real" security that only God can provide.

Women sādhus, like Ganga Giri, locate Mira Bai within a nirguna tradition to claim a female religious heroine who "performs" the power and capacity of women to unite with the nirguna Lord, and as such, to illustrate that women are as eligible as men for experiencing non-dual Brahman consciousness. The poetry of Kabir, Guru Nanak, and Ravi Das, who came from a formerly "untouchable" caste group, have clearly made the case that anyone can experience the nirguna Lord. Much like the poetry that is attributed to Mira Bai, these sants similarly extol the power of surrendering to the nirguna Ram. However, the historical examples tend to privilege male exemplars, rather than women exemplars, in representing nirguna devotion. The song traditions of the women sādhus balance this representation out by bringing the voices of female sants to the center of the nirguna tradition. As Ganga Giri says after she sang this bhajan, Mira Bai's attitude of surrender enabled her to know what she calls the "precious diamond" of Brahman-consciousness.

\subsection{Theme \#2: "Keeping the Precious Diamond": The Brahma-jnāna of Nirguna Devotion}

Another common metaphor on which the sādhus draw to describe their religious experiences of the nirguna Brahman involves the notion that knowledge of the impersonal absolute (Brahma-jnāna), as gained through nirguna practice, signifies the "precious diamond" by which they "earn" the authority (adhikarr) to unite with God. In comparison to studying sacred texts or practicing austerities like fasting, for instance, singing nirguna songs constitutes the preferred method for "melting into God" among the sādhus with whom I worked, because singing transforms their bodies into sacred instruments receptive to divine revelation, of which the liberating insight of the Brahma-jnanna ranks supreme. ${ }^{15}$ The sādhus liken nirguna bhajan performance to the chanting of Vedic mantras (sacred hymns and prayers containing liberating insight), which, in the history of Hindu traditions, has been a practice reserved for high-caste Brahmin men, and hence, off limits to women and low-castes. Many of the sādhus never learned the Vedas, and many of the women sādhus and some of the male sādhus never learned to read or write at all. Not having access to Vedic traditions of knowledge, however, was not an obstacle to their experiencing the nirguna Brahman, as the nirguna traditions not only accept "everyone" into its fold, but also challenge the so-called "high" authority of Vedic learning to determine the parameters for what "counts" as the Brahma-jnāna.

15 The cultural idiom of the body as receptive to divine inspiration, and thus, as an instrument of God is found in Hindu religious texts, such as the Bhagavad Gita. See (Patton 2008). It is also used by scholars to describe the "possessed" person's body who becomes a "receptive" instrument on which divine will works its power. See (Keller 2001). 
Regardless of their (former) caste status, most of the sādhus speak at length about the nirguna bhajan in terms of the sublime word (śabda), equivalent in power to the words of the Vedas ("Veda-vacana"). On a summer afternoon in 2005 while Ganga Giri, her disciple Tulsi Giri, and I paid a visit to the hermitage of another woman sādhu named Devi Nath, the sādhus broke out in a singing session to teach the significance of the nirguna bhajan for attaining Brahma-jnāna. Here is a song that they performed:

Listen my crazy [bāvlā] mind,

Without bhajans, you lose the diamond [hīrā]. Keep [the diamond] safe.

Listen my crazy [bāolā] mind,

Without bhajans, you lose the diamond. Keep it safe.

In this story, immortal rasas [juices] are filled.

Don't let your heart get attached with [worldly] things.

Listen my crazy mind,

In this story, immortal rasas are filled.

Don't let your heart get attached to [worldly] things.

Listen my crazy mind,

Without bhajans, you lose the diamond. Keep it safe.

Listen my crazy mind,

In this story, there is a quarry of diamonds.

Don't mix pebbles with the diamonds.

Listen my crazy mind,

In this story, there is a quarry of diamonds.

Don't mix pebbles with the diamonds.

Listen my crazy mind,

Without bhajans, you lose the diamond. Keep it safe.

In this story, unlimited water is filled.

Don't wash your clothes in mud.

Listen my crazy mind,

Without bhajans, you lose the diamond. Keep it safe.

Kabir says: 'Listen brother sādhus'.

Kabir says: 'Listen brother sādhus'.

It's only the sants who string one diamond after another.

Kabir says: 'Listen brother sādhus!'

It's only the sants who string one diamond after another.

Listen my crazy mind,

Without bhajans, you lose the diamond. Keep it safe. ${ }^{16}$

This bhajan contains a signature line attributed to Kabir who warns of losing the "precious diamond". As with most symbols, the diamond evokes multiple significations to suggest the notion of the $\bar{a} t m \bar{a}$, the Brahma-jnāna, and the attainment of nirguna Brahman-consciousness. Each of these represents a "precious" and "priceless" asset for the sādhu who seeks to transcend the transitory world of name and form. Perhaps the nirguna Lord itself requires such symbolic capital from the devotee in exchange for the priceless experience of transcendence. As Ganga Giri says in this singing session,

16 March 29, 2005. 
"one cannot get the best thing without the authority to have it". Singing nirguna bhajans (as opposed to studying the Vedas) grants the devotee the prized authority to meet God.

Addressing the "crazy mind", the bhajan calls attention to the devotee who has immersed herself in the intoxicating "juice" ("rasa") of bhajans by which she knows the $\bar{a} t m \bar{a}$, the Brahma-jnāna, and the nirguna Lord. Since bhajans provide access to the absolute, they, too, signify the precious diamond that the sādhu must guard with her life if she intends to meet Brahman. Focusing on nirguna worship rather than on worldly distractions and attachments helps the devotee to guard against losing the precious diamond. With that diamond the devotee disentangles herself from the web of samsāra, while advancing nearer to God. As the bhajan indicates, to savor the rasa of Brahman through the medium of the nirguna song amounts to an experience of transcendence. Thus, the bhajan makes a case for the primacy of nirguna bhakti as well as the importance of singing nirguna songs as often as possible every single day. For the devotee who keeps the practice of nirguna bhakti, the taste of God is sweet, indeed.

\subsection{Theme \#3: "The Taste of God Is Sweet": Nirguna Experience as Divine Bliss}

So far, we have learned that, along with cultivating the necessary devotional attitude of surrender, singing nirguna bhajans joins the devotee with the nirguna Lord. However, what is that union like? How does the experience of the impersonal Brahman feel? Does it evoke ecstasy or agony for the devotee? Is it a positive experience or a negative one? Hindu mystical texts such as the Upanisads, which are part of the (late) Vedic corpus of revealed literature, tend to talk about Brahman by adopting a "via negativa" approach. The Indian (Sanskrit) language idiom of "neti, neti" recurs throughout the Upanișadic narratives, which means "neither this, nor that", to emphasize that no finite human concept can describe or evoke understanding of what God is. Whatever is said about the impersonal Lord illustrates an approximate representation, which, in turn, only communicates a concept; ideas hardly substitute for actually experiencing the divine.

While the sādhus do not disagree with this notion (recall Ganga Giri's description of God as "slippery" - no idea encompasses the "reality" of divine experience), they opt for a "via positiva" approach for describing the qualities that they correlate with their experiences of Brahman. After all, their claim that God is knowable implies that God has qualities by which God can be known, and thus, experienced by the devotee. They also suggest that by knowing God's qualities through the means of religious experience something happens to the devotee, something occurs that changes her deep from within and inspires the devotee to plunge the depths of the ocean of divine experience even further, at least until the transcendence that is sought becomes a permanent state of consciousness. Psychologically speaking, if God could never be known through, albeit limited, human thought, why would anyone want to experience God in the first place?

Studying the nirguna bhajans of the sādhus, it becomes clear that their songs offer glimpses of hope and the satisfaction that derives from knowing Brahman. To that extent, the sādhus say either on the basis of the evidence of their songs (for many of them, nirguna songs articulate the divine experiences of the sants), or their own personal experiences, as evoked through bhajan singing, which the "taste of God" (Ramrasa) is "sweet" (mīthā), like "sugar", and yet infinitely better than sugar; that the experience produces a "blissful" (ānanda-may $\bar{\imath})$ consciousness, in which the sādhu steps beyond her ego-self and expands into the divine horizon of God-self. Their descriptions point to mystical union with Brahman as a sublime experience of divine ecstasy (the agony, as I am told, occurs when its over). The devotee becomes "high" on God without moving "up" or "down" in her emotional state. As a male sādhu by named Prem Nath explains to me while holding satsang at his ashram in the company of Tulsi Giri and Ganga Giri, the ecstasy (annanda) that he feels in those moments in which he "melts into" God-consciousness can be called "peace" (śānti). After he makes this provocative statement, Ganga Giri leads a singing session and performs these two bhajans: 
Song \#1

I offer food before [you, O Lord]

I forgot my house

I sacrificed good food,

$\mathrm{O}$, my brother,

If you drink you will become immortal

The 'juice' of Ram is sweet, my brother

The whole world drinks sweet things

No one drinks bitter things

The whole world drinks sweet things

No one drinks bitter things

The ones who will drink the bitter things

The ones who will drink the bitter things

They shall become the sweetest

The juice of Ram is sweet, my brother

If you drink this, you will become immortal.

The juice of Ram is like this, my brother

The whole world goes up,

Nobody goes down.

The whole world goes up,

Nobody goes down.

The one who goes down

The one who goes down

$\mathrm{S} /$ He shall become the highest

The juice of Ram is sweet, my brother.

Drink the knowledge and become immortal.

The juice of Ram is like this, my brother

Dhruv drank it [Ramras]

Prahlad drank it

The butcher drank it

Dhruv drank it

Prahlad drank it

The butcher drank it

The servant, Kabir, drank it fully

The servant, Kabir, drank it fully.

And they still have the desire of drinking more

The juice of Ram is sweet, my brother

Whoever drinks shall become immortal

The juice of Ramras is like this.

Song \#2

The urge to sing bhajans has really taken possession [over me.]

The Supreme Guru, Hari, is inside of my heart. 
Yes, the great words have taken possession [over me].

The Supreme Guru, Hari, is inside of my heart.

Oh, yes, great words have taken possession [over me].

The Supreme Guru, Hari, is inside of my heart.

Everybody is saying it has taken possession.

And, nobody is saying it has not.

Everybody is saying it has taken possession.

And, nobody is saying it has not.

But when it takes possession of a knowing person,

$\mathrm{S} /$ he forgets about her body.

The Supreme Guru, Hari, is inside of my heart.

Yes, the urge to sing bhajans has really taken possession [of me].

The Supreme Guru, Hari, is inside of my heart.

It took possession over Dhruva,

It took possession over Prahlad,

And it took over the butcher.

It took possession over Dhruva

It took possession over Prahlad

And it took over the Prostitute,

Who was not having qualities.

And it possessed Mira Bai in such a way [that]

She left the comforts of the palace.

The Supreme Guru is inside of my heart.

It possessed Rama

It possessed Lakshmana

It possessed mother, Sita.

It possessed Hanuman in such a way [that]

He jumped into the water.

The Supreme Guru is inside of my heart.

The Supreme Hari is inside of my heart.

The urge to sing bhajans has really possessed [me].

The Supreme Guru, Hari, is inside of my heart.

It possessed Bharathari in such a way [that]

He left the comforts of the palace.

And Gopichand left sixteen [wives].

The Supreme Guru, Hari, is inside of my heart.

It possessed Dhanna, Pipa, Ravidas, and Pumba.

And, it possessed the barber, Senva.

It possessed Dhanna, Pipa, Ravidas, and Pumba.

And, it possessed Senva. 
The Supreme Guru, Hari, is inside of my heart. ${ }^{17}$

After Ganga Giri sings the first few lines of the bhajans, Tulsi Giri joins in the bhajan session. While Prem Nath does not sing along with Ganga Giri and Tulsi Giri (though he sings other songs that he knew), he closes his eyes and allows his body to move to the rhythm of their performance, at times calling out "Hey Bhagvan" (Oh Lord) in response to the bhajans' refrains, particularly, as I recall, the refrain illustrated in the second song with the line, "The Supreme Guru, Hari, is inside of my heart". Their singing squeezes out the elixir that, like the devotees named in the songs, Prem Nath "drinks" by listening to the bhajan, filling him with the bliss that these sādhus suggest resembles the infinite power of Brahman to engulf the devotee rapt in mystical union.

Both bhajans speak of devotees who attained the "immortal" consciousness of the nirguna Lord by singing to God. The names of the devotees featured in these bhajans similarly appear in Hindu mythological texts, such as the Purānas, and texts that are linked to nirguna authors, like Jan Gopal. ${ }^{18}$ In the songs, we encounter the names of famous sants, such as Kabir and Mira Bai, and other devotees, too, like Dhruva, Prahlad, Gopichand, and Bharathari. Even figures featured in Rāmāyana narrative traditions like Ram and Sita, avatāras of Vishnu and his wife Lakshmi, and Lakshman (Ram's brother) and the monkey-god Hanuman, are mentioned to press on the intoxicating power of bhajan on deities, too. That such an impressive number of great personalities have attained transcendence suggests that the experience is available to anyone who longs for it and that nirguna bhakti makes it happen. As the first song says, "the urge to sing" bhajans generates an ecstatic state of awareness that compares to being possessed, or "taken over" by Brahman. That is, the force of Brahman-consciousness consumes the consciousness of the devotee so much so that she loses all sense of ego-self ("I" awareness), forgets her body, leaves the comforts of food, home, safety, and status to realize a state of transcendence in which dualities collapse into the unity of Brahman.

By the same token, merging into Brahman-consciousness seems to produce something else besides ecstasy. It seems that the intensity that is associated with transcendence engenders the concomitant excess of power, a spiritual residue, so to speak, which lingers in the devotee's awareness, reminding her of Brahman, even as it drives her to "drink" more of Brahman. In the views of the bhajans, to be swept away by the immaterial Brahman produces material effects on the body and the mind. Those material effects, as the sādhus teach, represent spiritual transformation caused by nirguna worship. Similarly, self-transformation results, in part, because the excess acts upon human consciousness, chiseling away destructive layers of ego-self until the gateway to the $\bar{a} t m \bar{a}$, that is, Brahman shines brilliantly. Could it be that the excess generated by nirguna devotion contains something of Brahman itself? Like the sea foam that is made from the churning of the ocean. Could that excess possess shades of the qualities of Brahman that register in the devotee's consciousness as "sweet" and "sublime"? The sādhus and their bhajans respond in kind with an emphatic "yes!"

\section{Conclusions: “Wake up, Traveler!"-The Transcendence of Nirguna Bhakti}

From the perspectives of the sādhus, the "difficult" path of nirguna bhakti leads a person to experience an unusual world in which the attributes of gender (or sex), name, form, status, and wealth, and whatever else a society deems as worthy of importance mean nothing in the divine encounter with the impersonal Brahman. Rather, the symbolic currency accepted by the nameless and formless divine absolute concerns cultivating qualities that can neither be seen nor measured, such as "love", "devotion", "commitment", "surrender", and "perseverance", and by which the Brahma-jnāna is revealed. Developing these traits molds the devotee into a receptive instrument of God who is prepared to understand and apply the liberating knowledge that not only makes self-transformation (and release from rebirth) possible, but it also brings the transcendence that is characterized by divine

17 November 19, 2005.

18 See (Lorenzen 1996). 
mystical union to bear on human consciousness. I would imagine that for people who have been denied by religious orthodoxy the right to meet God because of their gender or perceived low status, transcending social differences illustrative of the mundane must come as a great relief. Many times over the course of my research I have observed women sādhus refuse to be seen and understood through the constricting lens of dominant patriarchal ideas of womanhood, and low-caste sādhus overturn high-caste notions of "purity" and "pollution", by singing of the nirguna devotion that disdains social hierarchies with every fiber of its being.

As the bhajans of the sādhus suggest, singing songs to (and about) the nirguna Lord endows them with the salvific power, authority, and insight to know and become God. The religious prestige ascribed to sādhus like Ganga Giri, Tulsi Giri, Devi Nath, and Prem Nath by devotees and non-devotees alike is in large part derived from their perceived expertise in nirguna knowledge, which they have acquired from the many long years they spent singing nirguna bhajans. Their songs inspire the courage that, according to the sādhus, remains necessary for the radical life of sannyāsa. At the same time, through the use of metaphors, symbols, and idioms, their bhajans describe an "upside-down"19 form of language consistent with the religious poetics of nirguna traditions (i.e., a language that defies conventional logic) that the impersonal Lord can be understood and experienced. Resorting to a via positiva approach, their songs talk of "tasting" and "drinking" the unlimited "sweetness" of the sublime "bliss" of the absolute Brahman; of being overtaken by the infinite wave of God-consciousness; and, of "dissolving into" an eternal ocean of God-self that drowns out individual awareness.

And yet, as the sādhus and their songs remind us, no word, symbol, or idea substitutes for actual experience of Brahman. The "prize" of "earning" Brahman comes to those who combine good old-fashioned effort with a sincere attitude of dependence on God. As significantly, for the sādhus, experiencing nirguna as opposed to saguna worship really is not the "truth" of the matter for why they do what they do. The point is to transcend all human categories-including those that scholars (such as this author) emphasize in the effort to earn academic capital-that mire people in the trappings of samsāra and "get God". Nirguna worship brings the sādhus to that impersonal level of divine experience, and so they take this "boat", which is costlier than others, to cross over the ocean of worldly existence. Much like Kabir implores in the bhajan featured in the beginning of the article, "Hindus, Muslims, where did they come from", the sādhus also say "pay no attention to categories" as they lack "real" meaning for the one who wants God. To "win" the nirguna Lord means, in the words of the sādhus' bhajans, to "wake up" at last from the deep slumber that represents human existence in samsāra. Thus, I leave my readers with one last bhajan as sung by Tulsi Giri at her ashram in the year 2005. Its title is "Wake up, Traveler! Morning has come". Here is that bhajan.

Wake up, traveler, morning has come

It's morning now. Nevertheless, [the traveler] still sleeps.

Wake up, traveler, morning has come.+*

The one who sleeps [is] the one who loses everything The one who sleeps [is] the one who loses everything The one who remains awake, s/he gets everything The one who remains awake, $\mathrm{s} /$ he gets everything.

Without satsang, there is no insight

Without satsang, there is no insight

From where will you find knowledge?

From where will you find knowledge?

Wake Up traveler, morning has come. ${ }^{20}$

19 See (Hawley and Juergensmeyer [1998] 2008), p. 41

20 July 21, 2005. 
Funding: This research was funded by a Junior Scholar Dissertation Research Fellowship by the American Institute of Indian Studies between 2004 and 2006.

Conflicts of Interest: The authors declare no conflict of interest.

\section{References}

Bourdieu, Pierre. 1985. Forms of Capital. In The Handbook of Theory and Research for the Sociology of Education. Edited by John Richardson. Westport: Greenwood Publishers, pp. 46-58.

DeNapoli, Antoinette E. 2014. Real Sadhus Sing to God: Gender, Asceticism, and Vernacular Religion in Rajasthan. New York: Oxford University Press.

Dimmitt, Cornelia, and J. A. B. van Buitenen, eds. 1978. Classical Hindu Mythology: A Reader in the Sanskrit Puranas. Philadelphia: Temple University Press.

Hawley, John Stratton, and Mark Juergensmeyer. 2008. Songs of the Saints of India. Oxford: Oxford University Press. First published 1998.

Keller, Mary. 2001. The Hammer and The Flute: Women, Power, and Spirit Possession. Baltimore: The Johns Hopkins University Press.

Lorenzen, David. 1996. Praises to a Formless God: Nirguñ̄ Texts from North India. Albany: State University of New York Press.

Olivelle, Patrick, trans. 1996. Upanișads: A New Translation. Oxford: Oxford University Press.

Patton, Laurie L., trans. 2008. The Bhagavad Gita. New York: Penguin Books.

(C) 2018 by the author. Licensee MDPI, Basel, Switzerland. This article is an open access article distributed under the terms and conditions of the Creative Commons Attribution (CC BY) license (http:/ / creativecommons.org/licenses/by/4.0/). 